\title{
Mouthparts, gut contents, and retreat-construction by the wood-dwelling larvae of Lype phaeopa (Trichoptera: Psychomyiidae)
}

\author{
Bernd SPÄNHOFF ${ }^{1}$, Ulf SCHULTE $^{1}$, Christian ALECKE ${ }^{2}$, Norbert KASCHEK ${ }^{1}$ and Elisabeth Irmgard MEYER ${ }^{1}$ \\ ${ }^{1}$ Institute for Animal Evolution and Ecology, Department of Limnology, University of Muenster, 48149 Muenster, Germany; e-mail: \\ spanhof@uni-muenster.de \\ ${ }^{2}$ Max Delbrueck Center for Molecular Medicine, 13125 Berlin, Germany
}

Key words. Retreat-construction, habitat specialization, woody debris, sensilla, mouthparts, gut contents

\begin{abstract}
The larvae of Lype phaeopa (Stephens, 1836) are found on dead wood substrates in streams and lakes. Gut content analyses, scanning electron microscopy of larval mouthparts, and gallery structure revealed characteristics of this habitat preference. The guts of the larvae contained mainly wood fragments whereas other food items (detritus, algae, fungi, inorganic particles) were much rarer. The suitability of the mouthparts to scrape wood surfaces, and the adaptative elongation of the silk-secreting spinneret, which facilitates the construction of retreats consisting of a tunnel-like silken net incorporating mainly wood fragments, are discussed. Retreat-construction under laboratory conditions indicated that larvae exploit new feeding areas by steadily extending their galleries.

Tips of the maxillary palps bear five sensilla styloconica and five sensilla basiconica, almost all bearing an apical pore. Three sensilla styloconica, two with an apical peg, and two small inconspicious sensilla basiconica are located on the galea. Possible function of these sensilla is discussed on the basis of studies on the closely related sister-group of Lepidoptera.
\end{abstract}

\section{INTRODUCTION}

Obligate associations of aquatic invertebrate species with submerged wood are rarely investigated. Although Dudley \& Anderson (1982) reported 45 species that were closely associated with such substrates and Pereira et al. (1982) showed that a remarkable number of these species ingest wood, this association has been examined in detail for only few species. The complete larval development of aquatic insects associated with submerged wood is reported for the dipterans Lipsothrix spp. Loew, 1879 (Dudley \& Anderson, 1987) and Xylotopus par (Coquillett, 1905) (Kaufman \& King, 1987), the coleopterans Macronychus glabratus Say, 1825 (Phillips, 1997) and Lara avara LeConte, 1852 (Steedman \& Anderson, 1985), the tropical ephemeropterans Povilla adusta Navas, 1912 and Asthenopus spp. Eaton, 1871 (Sattler, 1967; Tobias, 1996), and the trichopteran Lasiocephala basalis (Kolenati, 1848) (Hoffmann, 2000).

Several Trichoptera species are associated with woody debris in streams (Sattler, 1957; Anderson et al., 1984; St Clair, 1994; Collier \& Halliday, 2000; Hoffmann, 2000). However, under natural conditions only larvae of the genus Lype MacLachlan, 1878 pass their whole larval development, including the pupal stage, on woody debris (Hickin, 1950; Hickin, 1954; Wiberg-Larsen, 1995; Spänhoff et al., 2000a). To supplement their feeding requirements due to the low nutritional value of wood all other species switch to another substrate at least once during their larval development. Thus, although Lasiocephala basalis was reared from egg to adult in the laboratory exclusively on alder wood, the highly mobile larvae exploit other food sources under natural conditions (Hoffmann, 2000).
Lype and other genera of Psychomyiidae construct tunnel-shaped retreats on various submerged substrates (Edington \& Alderson, 1973). The Central European species of Tinodes Curtis, 1834 and Psychomyia Latreille, 1829 prefer to attach their retreats to mineral substrates, whereas Lype colonizes mainly wooden surfaces (Alderson, 1969; Wiberg-Larsen, 1995). Accordingly, the larvae of Tinodes feeding on epilithic algae, especially diatoms (Becker, 1990; Alecke, 1998), and the gut of L. phaeopa contains a high proportion of wooden fragments (Spänhoff et al., 1999) despite the low energy value of this food resource.

The number, distribution and function of sensilla on the mouthparts of terrestrial insect larvae play an important role in detecting feeding resources and evaluating their quality prior to ingestion (Zacharuk \& Shields, 1991; Shields, 1996). We are, however, not aware of such studies on aquatic species. The purpose of the present study is to link mouthpart morphology and associated sensilla with the mode of feeding in an aquatic larva of a trichopteran.

\section{MATERIAL AND METHODS}

\section{Study site}

Lype phaeopa populations in streams in NorthrhineWestphalia (Germany) were investigated. The main study site was the Ladberger Muehlenbach, a sandy lowland stream located $30 \mathrm{~km}$ northeast from the city of Muenster. Larvae of Lype phaeopa were collected from the midsector of a stream, which is bordered by an almost natural riparian woodland consisting mainly of black alder (Alnus glutinosa (L.) Gaertner) and some oak species, mainly common oak (Quercus robur L.). Additionally, willow (Salix spp. L.) and hazel (Corylus avellana L.) shrubs are abundant. 


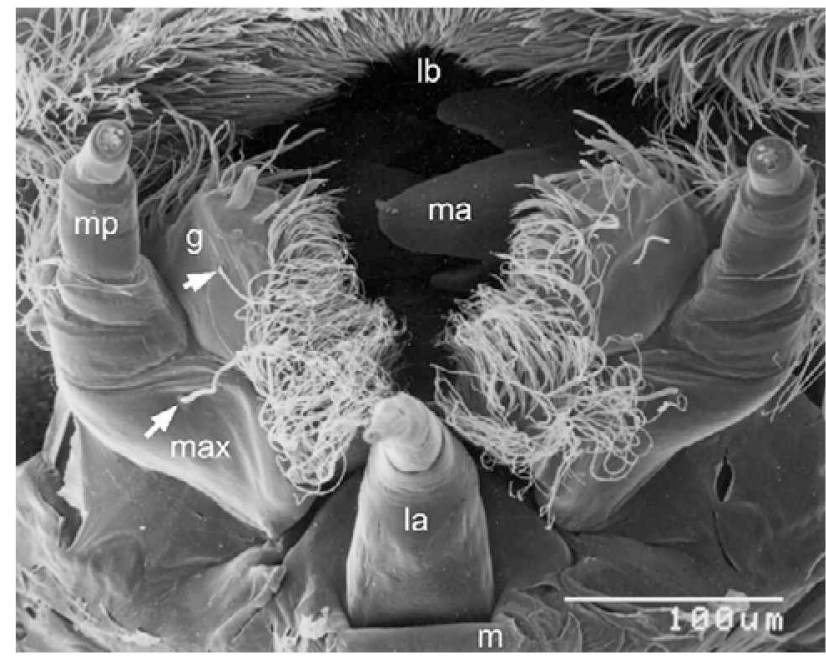

Fig. 1. Frontal view of the larval mouthparts with mandible (ma), tip of the labrum (lb) with several bristles and hairs, maxillary palp $(\mathrm{mp})$, palpiger of the maxilla $(\max )$, galea $(\mathrm{g})$, labium (la) and mentum (m). White arrows denote chaetic sensilla.

\section{Laboratory investigations}

Gut content analyses were performed on fifth instar larvae. Ten samples were prepared, each sample consisted of the pooled gut contents of five to seven larvae, which were dissected immediately before the analysis. Gut tissues were removed, the contents briefly subjected to ultrasound, and the resultant suspension filtered through a cellulose-nitrate-filter (pore size 0.45 $\mu \mathrm{m})$. The filters were cleared with immersion oil and inspected under a microscope, which was linked via a black/white ccdcamera to a computer for subsequent image analysis. Five display details were randomly chosen at 100 fold magnification for each sample. Particles were classified into the following food categories: wood fragments, fungal hyphae, inorganic substances, algae and amorphous detritus. The area covered by each food category was estimated using an image-analyser software (OPTIMAS 5.0).

The morphology of the larval head was investigated by scanning electron microscopy (SEM). Sensilla located on the mouthparts were classified according to Zacharuk \& Shields (1991), Shields (1994a, b) and Faucheux (1995).

The organic contents included in retreats (galleries) collected from the streams and obtained by rearing larvae in the laboratory (see below) were analysed. Gallery material was dried at $105^{\circ} \mathrm{C}$ and then burned in a furnace at $550^{\circ} \mathrm{C}$. Organic content was calculated as combustion loss. Amounts of particulate organic matter (POM) in galleries from different sources (natural samples vs. laboratory rearings) were tested for statistically significant differences by a t-test performed with SPSS 10.05 .

Construction of larval retreats was studied under laboratory conditions. For this 39 larvae (5th instar) were collected and exposed to uncolonised slightly decayed submerged branches in glass aquaria filled with aerated stream water. The aquaria $(80 \times$ $80 \times 30 \mathrm{~cm}$ ) were kept in a computer controlled climate chamber, which regulated temperature and the dark-light rhythm to outdoor conditions. Gallery lengths were measured every 12 hours for the first ten days, and then at irregular intervals, by marking the gallery-edges with coloured pins. Additionally, the structure of selected galleries and single silken filaments were investigated using SEM.

\section{RESULTS}

Morphology of the mouthparts and first legs of larvae

The frontal part of the sclerotized labrum bears many strong, differently sized bristles (Fig. 1). A part of maxilla is fused to labium (forming a maxillolabium), while the remaining part of the maxilla bears the maxillary palp, and the labium is reduced to an elongated process on which is situated a remarkably extended spinneret. Labial palps are completely absent. The median part of the galea is densely covered by hair-like structures, whereas some differently shaped sensilla are located on the lateral part. The apex of the maxillary palps is retractile (Figs 1, 2a, 5a) and bears several sensilla. Posteriorly, two sensilla chaetica are located on the ventral side of the spinneret (Fig. 2a). The posterior part of the spinneret is subdivided into a tube-like ventral part in which the dorsal part is embedded. The orifice at the tip of the spinneret is a knob-like structure with a round opening (Fig. 2b). Frontal pressure on the spinneret tip (occuring e.g., when the larva attaches a silken thread to a wooden surface) results in a response of the dorso-ventrally subdivided structure, by pushing the dorsal part backwards (Fig. 2c). No antennae and labial palps were found on the heads of L. phaeopa larvae. The ventral sides of the anterior tarsi bear several comb-like structures (Figs 3a, b). These structures are all directed anteriorly towards the ventral margin of the leg. Tarsi of the 2 nd and 3 rd legs lack these structures.

\section{Number and distribution of sensilla on larval mouthparts}

One long sensillum chaeticum is located on the posterior side of palpiger and galea of each maxilla, respectively (Fig. 1). Overall, there are ten finger-like, five styloconical and five elongated basiconical sensilla located on the tip of the maxillary palps (Fig. 4). Most of the sensilla bear an apical pore, except one basiconical sensillum, which shows a larger pore located laterally (Fig. 4).

The galea bears two inconspicious knob-like sensilla basiconica posteriorly, with terminal pores (Fig 5a), and three sensilla styloconica, two of these consisting of a basal stylus and an apical peg (Figs 5a, b). The lateral of the two sensilla is branched approximately halfway along its length, one part bearing an apical peg and the other a long trichoid sensillum (Figs 5a, b). Pegs of both sensilla show an apical pore. The third styloconical sensillum is located between the previously described two, but this sensillum styloconicum bears a very small conical peg subapically and is therefore morphologically slightly different from the other two sensilla styloconica (Fig. 5b). Another trichoid sensillum arising from a socket is located at the lateral styloconical sensillum (Figs 5a, b).

\section{Gut contents}

Guts contained mainly fragments of wood $(88.5 \% \pm$ 5.8; Fig. 6). Amorphous detritus, which could not be categorized, was the second most important component $(7.5 \%$ $\pm 3.7 \mathrm{SD})$. Other dietary compounds like algae $(0.05 \% \pm$ 

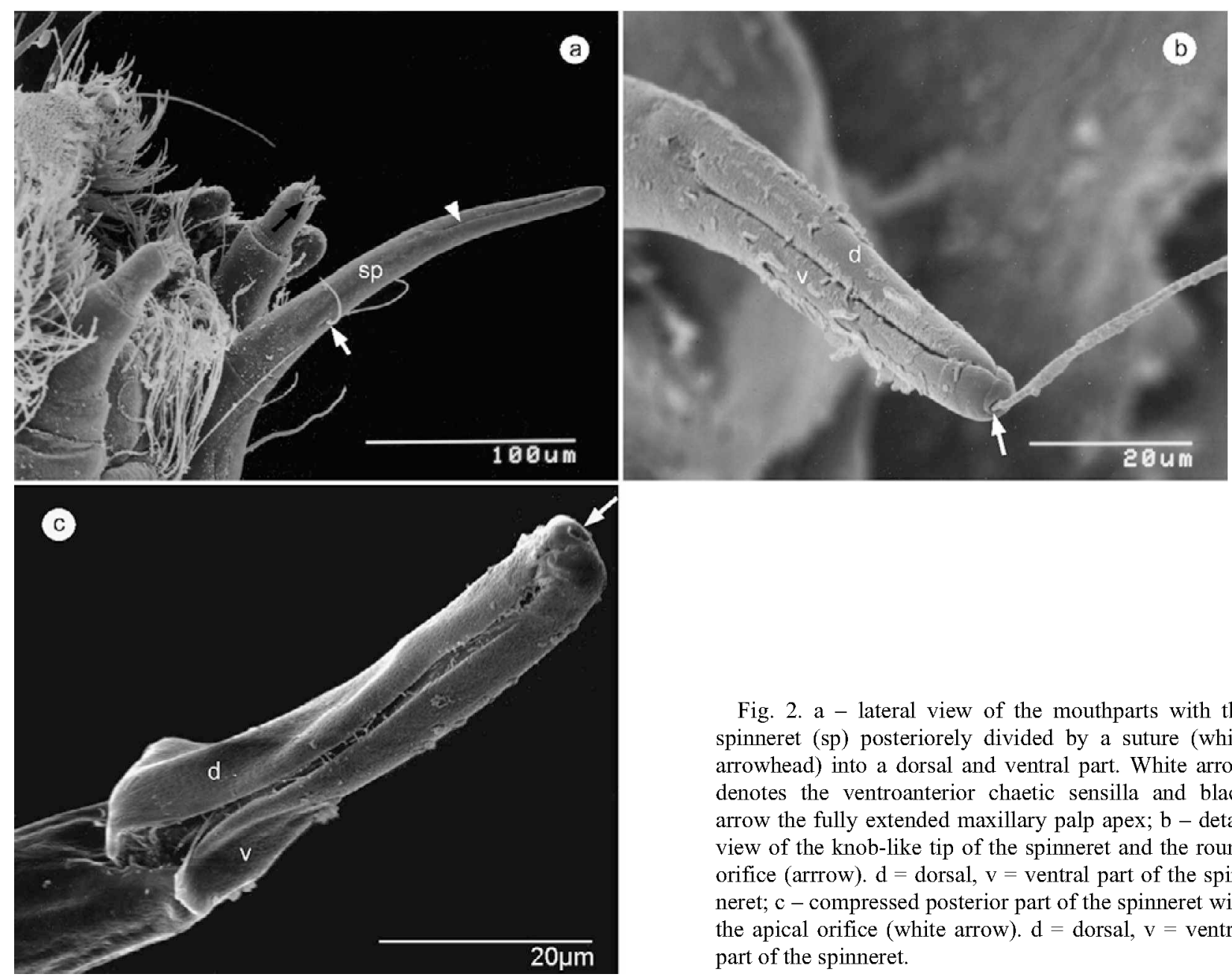

Fig. 2. a - lateral view of the mouthparts with the spinneret (sp) posteriorely divided by a suture (white arrowhead) into a dorsal and ventral part. White arrow denotes the ventroanterior chaetic sensilla and black arrow the fully extended maxillary palp apex; $b$ - detail view of the knob-like tip of the spinneret and the round orifice (arrrow). $d=$ dorsal, $v=$ ventral part of the spinneret; $\mathrm{c}$-compressed posterior part of the spinneret with the apical orifice (white arrow). $d=$ dorsal, $v=$ ventral part of the spinneret.

$0.19)$ and fungal hyphae $(1.8 \% \pm 2.9)$ were rarely recorded. Inorganic particles were probably ingested accidentally $(2.2 \% \pm 3.6)$.

\section{Gallery-construction}

5th instar larvae rapidly constructed new galleries, after being removed from their old galleries and transferred to

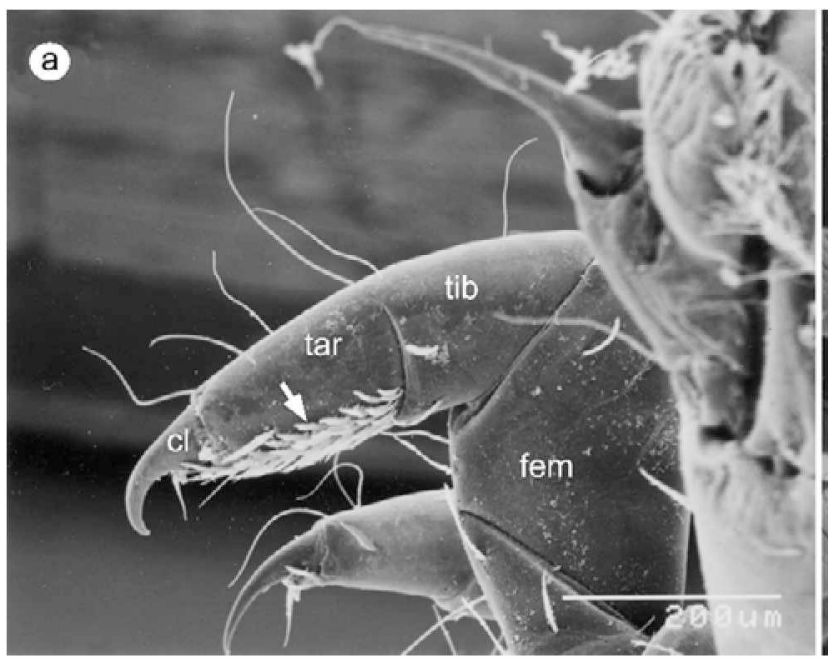

another substrate. Following a very quick initial phase of gallery-construction (15.8 mm mean length in 12 hours) the larvae worked continously but more slowly on the extension of the galleries. This gallery extension increased linearly with time (Fig. 7). Galleries constructed under laboratory conditions consisted almost

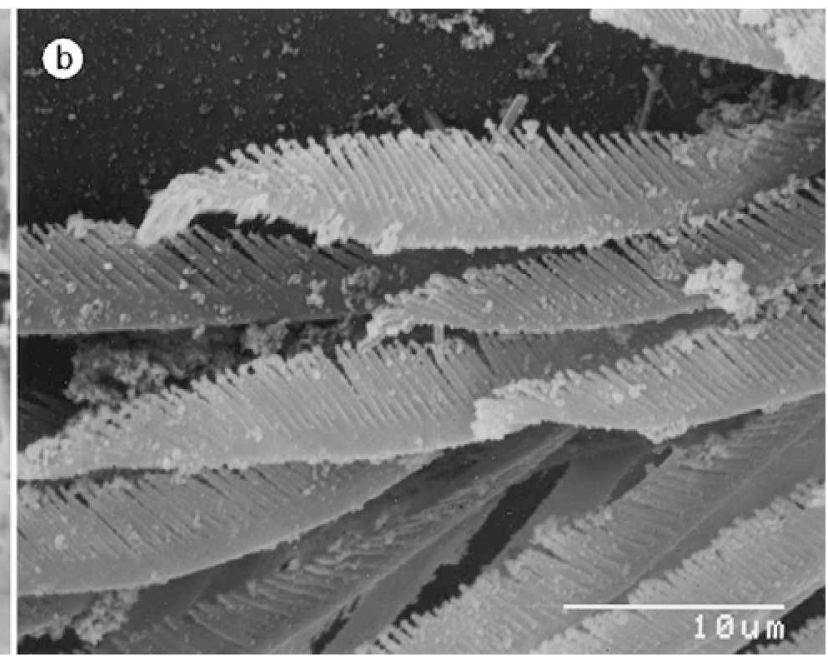

Fig. 3. a - first leg of larva with femora (fem), tibia (tib), tarsus (tar) bearing several comb-like bristles on the ventral edge (white arrow) and the terminal claw (cl); $\mathrm{b}$ - detail view of the comb shaped bristles. 


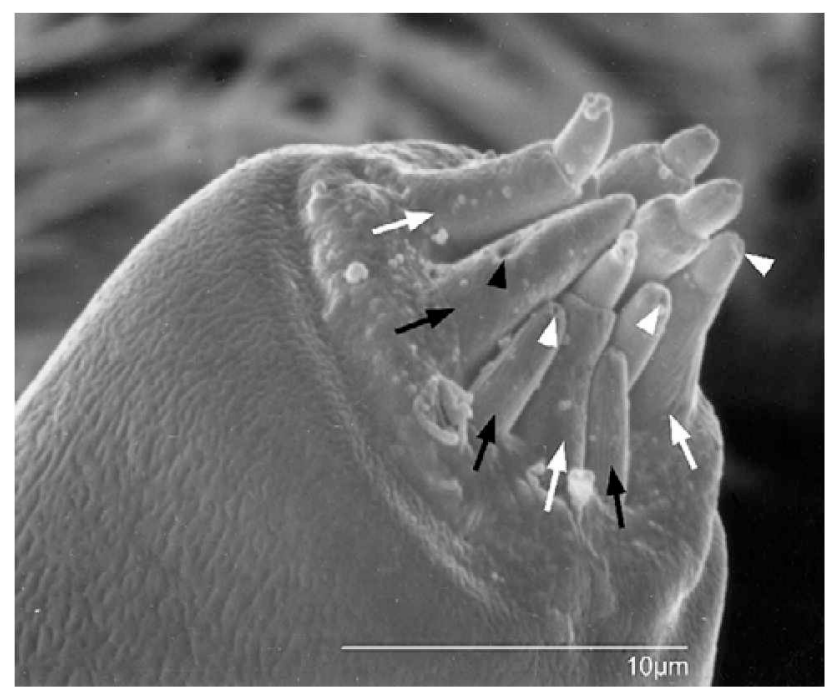

Fig. 4. Apex of a maxillary palp with elongated sensilla basiconica (black arrows) and sensilla styloconica (white arrows). Each sensillum shows an apical pore (white arrowheads), excepting one basiconical sensillum with a large pore (black arrowhead) halfway along its length.

exclusively of wooden fragments, whereas galleries taken from natural situation contained a significantly higher proportion of inorganic compounds (Fig. 8).

SEM-studies showed that the gallery is a tunnel-like construction, which covers a hollow corridor on the surface of the wood (Fig. 9a). These grooves are either natural crevices on the wood surface or they were produced by the larvae. This was indicated by the colour of the groove bottom, which was very often much brighter than the dark wood surface surrounding the grooves.

The retreat-construction is tightened by threads fixed to the wood surface on both sides of the gallery (Fig. 9b). The attachment points of these threads indicate the viscous, glue-like consistency of the silken secretion (Fig. 9b). Tension of the threads is indicated by their curled appearance after being torn off (Fig. 10a).

The inner walls of the galleries were constructed by a loosely woven net consisting of double-stranded silken threads, in which fragments of wood were incorporated (Figs 10a, b).

\section{DISCUSSION}

\section{Head morphology and feeding mode of the larvae}

Matsuda (1965) described the origin of the spinneret in Trichoptera and Lepidoptera as an "intimate fusion of the labium and hypopharynx", which explains the dorsoventrally arranged structure of the spinneret.

When feeding the larvae scrape off the outer surface layers of wood with their strong mandibles, collect the fragments with their anterior legs, where comb-like structures are situated on the ventral edge, and use the strong bristles on the front edge of the sclerotized labrum and numerous hairs covering great parts of the galea to ingest the wood fragments.

Although biofilm constituents are only a minor part of the gut content, sensilla located on the tip of maxillary palps are probably used to locate this qualitatively important food resource.

The nutritional value of woody debris is low and the larvae have only a limited capability for digesting wood components (Schulte et al., in press). Therefore, although wood components dominate in the gut content, the primary food resource is probably the epixylic biofilm. This is further supported by the univoltine life cycle as compared with an extended larval development of wood feeding insects (Anderson et al., 1984; Slansky \& Scriber, 1985).

Antennal sensilla for long- and short-range detection of olfactory stimuli are important in adult insects, whereas taste and tactile receptors are more important in the rela-
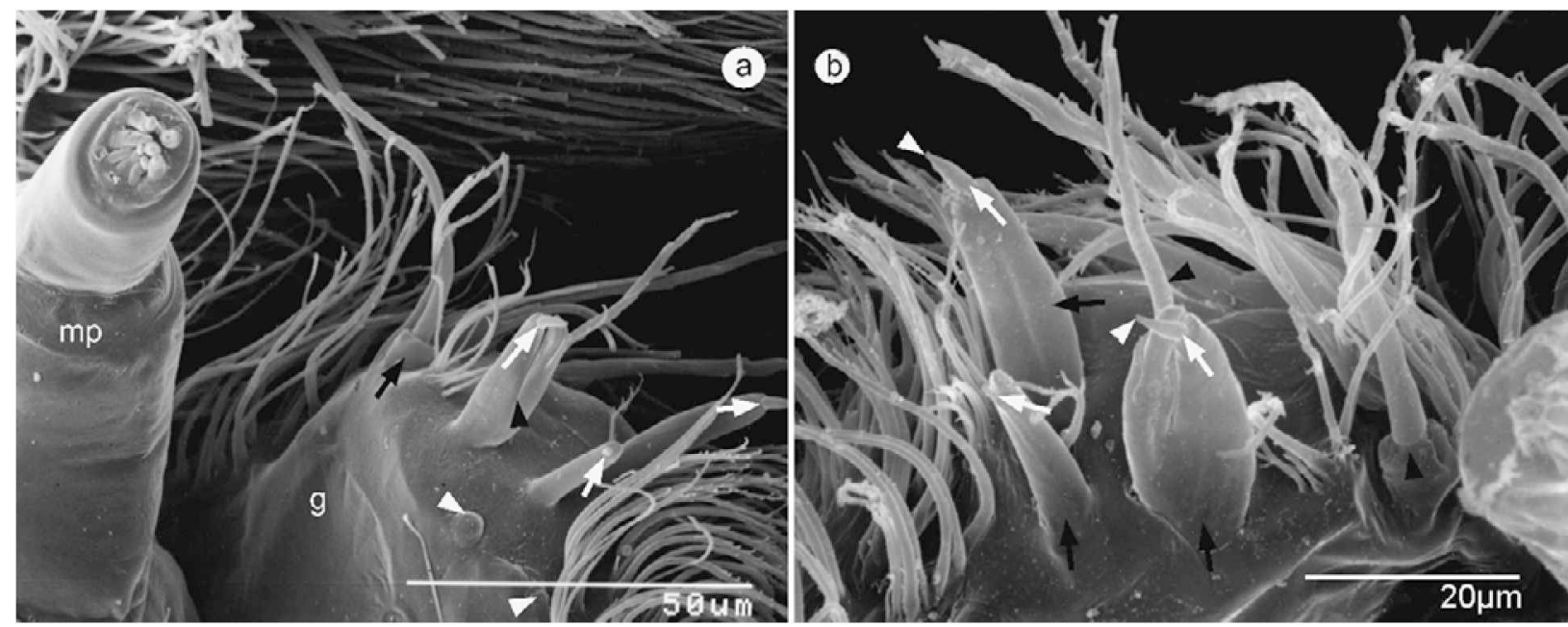

Fig. 5. a - lateral edge of the galea bearing different sensilla. Sensilla basiconica with pores (white arrowheads), a socket sensillum trichoideum (black arrow) and three sensilla styloconica with terminal pegs (white arrows). The lateral styloconical sensilla is branched (black arrowhead) with one branch bearing a peg and the other a long bristle ( $\mathrm{mp}=$ maxillary palp, $\mathrm{g}=\mathrm{galea}) . \mathrm{b}-\mathrm{lateral}$ view of the styloconical sensilla (black arrows) of the galea, showing the pegs (white arrows) with apical pores (white arrowheads). The peg on the middle sensilla is much shorter compared to the other two sensilla. Black arrowhead denotes the sensilla trichoidea with its socket and the apical hair on the second branch of the lateral sensillum styloconicum. 


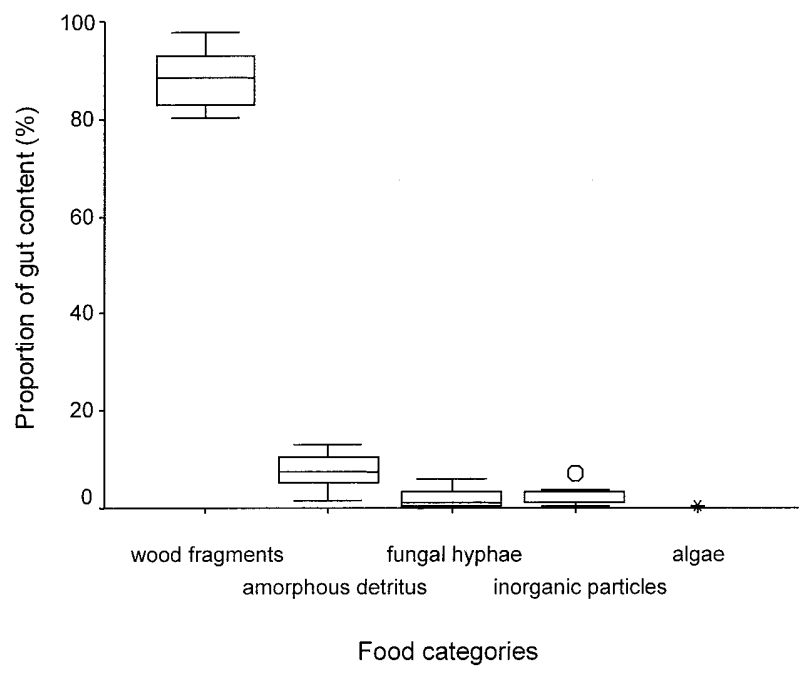

Fig. 6. Box plot of food categories in the guts of larvae (circle $=$ outliers, asterisk $=$ extreme values). Results are from 10 samples each containing the gut contents of 5 to $75^{\text {th }}$ instar larvae.

tively less mobile immature stages (Zacharuk \& Shields, 1991). Compared to other aquatic insect species (Gaino \& Rebora, 1999), the absence of antennae in Lype might be interpreted as a consequence of a semi-sessile life performance. Absent labial palps, and the exceedingly 'elongated' spinneret could have been specializations to their behaviour of constructing galleries.

Larvae of L. phaeopa show no preference for decay stages or particular species of wood (Spänhoff et al., 2000b). To exploit new feeding areas the larvae extend their galleries continuously under laboratory conditions.

\section{Distribution and function of mouthpart sensilla}

Although the function of the sensilla cannot be unambiguously determined by their external morphology observed by SEM-photography (Steinbrecht pers. comm.), their distribution and number in Lype phaeopa

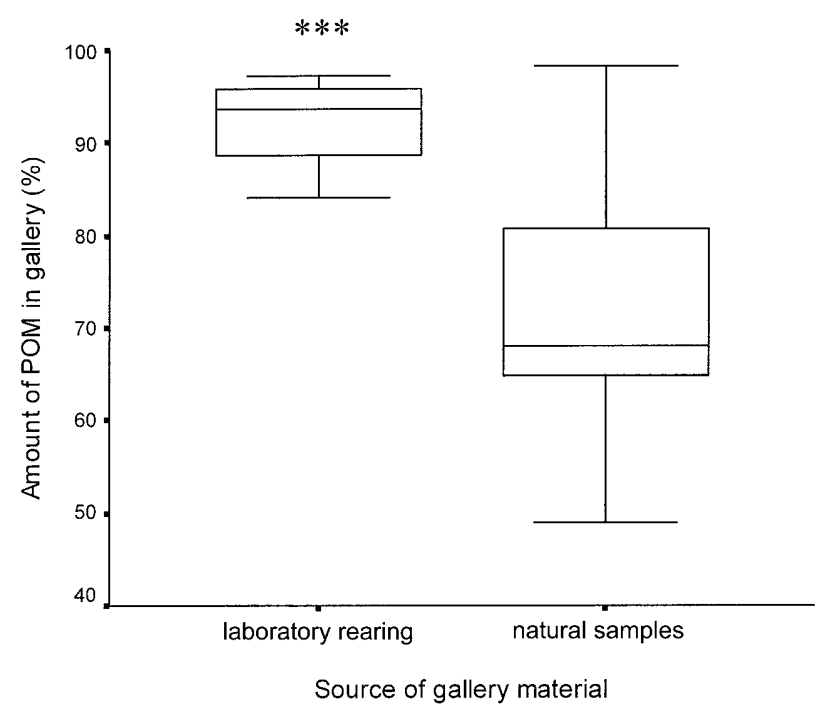

Fig. 8. Box plot of particulate organic matter (POM) in galleries collected in streams (natural samples) and from laboratory rearings $(* * *=p<0.001)$.

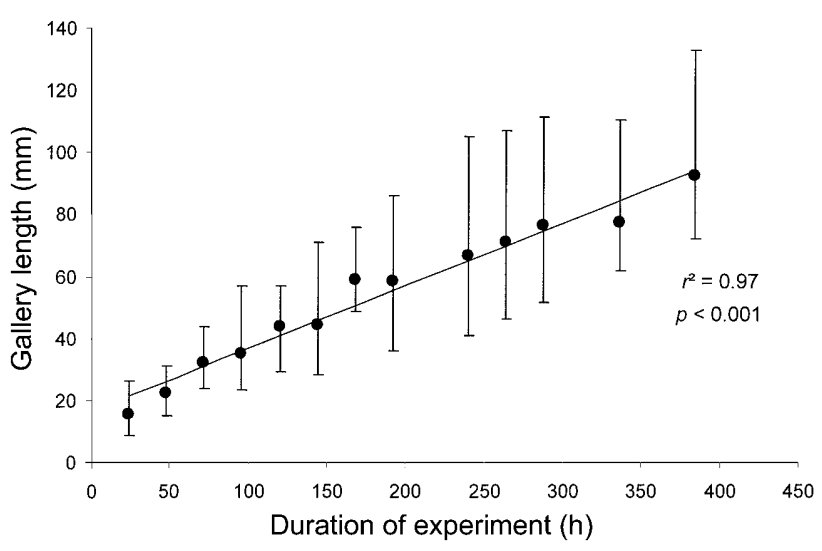

Fig. 7. The relation between the lengths of the galleries and time for $L$. phaeopa larvae kept under laboratory conditions. The values are presented as mean (points), minimum and maximum lengths (bars).

larvae indicate an important role in feeding. Sensilla on insect mouthparts are primarily contact gustatory or olfactory receptors for checking the chemical composition of substrates and for detecting food resources (Zacharuk \& Shields, 1991; Shields, 1996). The sensilla of lepidopteran larvae (e.g. Homoeosoma nebulella (Denis \& Schiffermüller, 1775), Mamestra configurata Walker, 1856) are slightly different from those of $L$. phaeopa larvae, but especially the number and distribution of sensilla on the galea (Shields, 1994a, b; Faucheux, 1995, Shields, 1996) indicate the sensilla function without histological and neurophysiological investigations.

In L. phaeopa, sensilla on the edge of the galea may fulfill proprioceptorial functions during ingestion of food items as in lepidopteran larvae (Faucheux, 1995; Shields, 1996). Two basiconical sensilla are mechanoreceptors responding to food particles before they enter the hypopharyngeal region. Further, the styloconical sensillum with the very small subapical peg resembles the so called spire-shaped sensillum basiconicum in lepidopteran larvae (Mamestra configurata), although this sensillum has a different external morphology (Shields 1994b, Shields 1996). Shields (1996) suggests that they are thermo-hygrosensitive, responding to temperature and moisture fluctuations, but these functions are useless in aquatic larvae. It is more likely that the sensillum has a tactile or gustatory function in L. phaeopa larvae, as the subapical peg is directed away from the hypopharyngeal region and comes into contact with food particles prior to ingestion. The other two styloconical sensilla are gustatory receptors in lepidopteran larvae (Shields, 1994a; Shields, 1996), which could be true for L. phaeopa larvae as well. These sensilla taste the chemical composition of food particles and determine whether they are ingested or rejected. Chemical stimuli are assessed via the apical pore of the styloconical sensilla as critically reviewed by Steinbrecht (1997). The trichoid sensillum on the galea coordinates the position and regulates the movement of the mandibles in relation to the maxillolabium to avoid mechanical damage during mastication (Shields, 1996). Location of the one observed trichoid sensillum in $L$. 


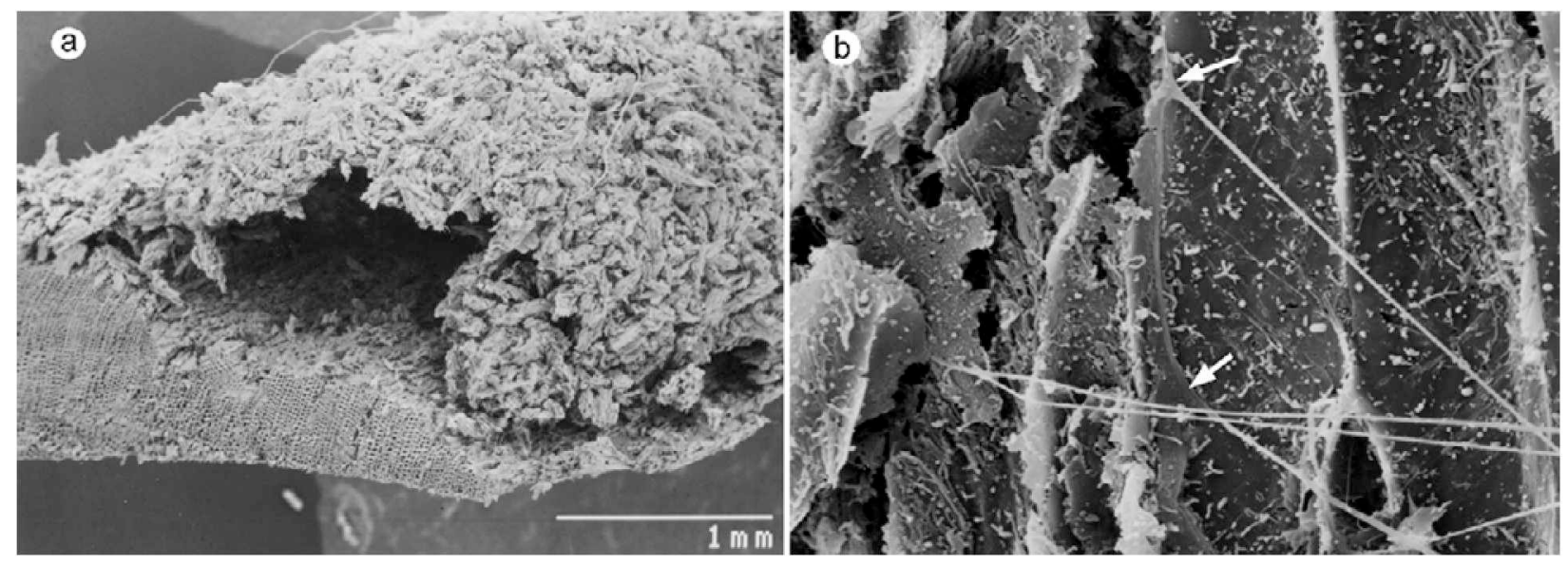

Fig. 9. a - cross section of larval gallery showing the tunnel-like shape of the retreat; $b$ - fixing threads of the gallery with their attachment points (arrows) on the wood surface.

phaeopa larvae supports this assumption, because of its prominent position on the lateral edge of the galea. Keil (1997) indicated that trichoid sensilla arising from a socket structure generally respond to mechanical stimuli by registering the direction from which the stimulus comes.

Other sensilla, like the sensilla chaetica on the ventral surface of the maxilla palpiger and the galea are mechanoreceptors, probably for spatial orientation of the larva of $L$. phaeopa within its gallery. The same may apply to several chaetic sensilla on the dorsal surface of the head. Movement of the larva within the gallery could be often observed, and were studied in detail for Tinodes species by Alecke (1998).

\section{Gallery-construction}

The galleries are commonly orientated in the direction of the wood fibers, but the water current may also influence the gallery construction (Tomaszewski, 1955). Under laboratory conditions and a relatively slow water current, the larvae preferably orientate their galleries in the fiber direction of the wood. In streams, retreats consist mainly of wood fragments and a few sand grains. However, this mineral material may be deposited on rather than incorporated into the gallery wall. In a laboratory experiment, where mineral material was scarce (but available), the galleries consisted almost exclusively $(92 \% \pm$ 4.9) of wood fragments. Galleries incorporating wood are rare in aquatic macroinvertebrates. Beside the Trichoptera, only Diptera (especially chironomids) secrete silk to construct tubes, which may account for the species richness of these two groups (Mackay \& Wiggins, 1979). However, no chironomid species is known to build tubes incorporating mainly fragments of wood. The wood-boring ephemeropteran larvae of Povilla burrow into submerged wood lining the walls of their tunnels with silk produced by their malpighian tubules. They are filter-feeders using submerged wood solely for tunnel construction and shelter (Sattler, 1967; Tobias, 1996). Case-bearing Trichoptera sometimes use wood fragments for their case-construction, but this is not comparable to
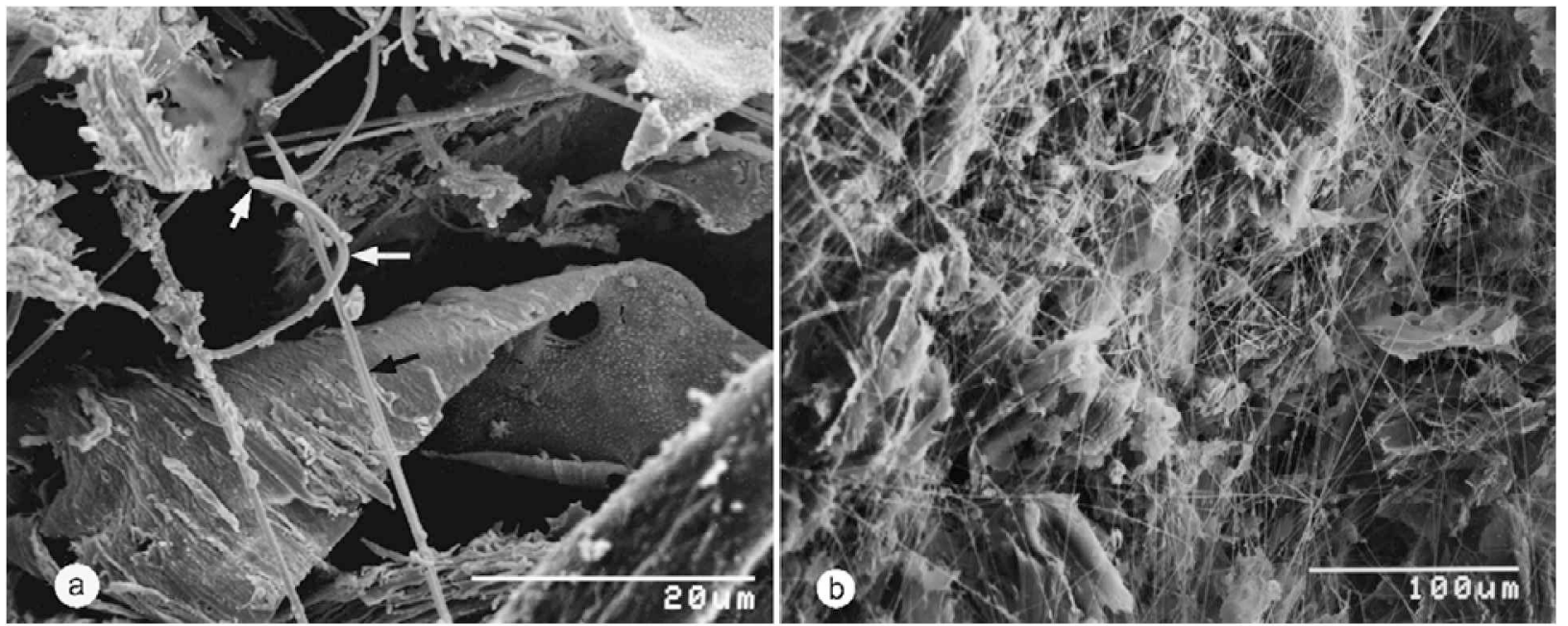

Fig. 10. a - inside view of a gallery, with a broken curled thread (white arrows) and some straight double stranded threads (black arrow); $b$ - inside view of a gallery showing the loosely woven net of silk filaments incorporating wood fragments. 
the extensive use of wood for retreat-making by $L$. phaeopa larvae.

The construction of fixed retreats is facilitated by the elongated spinneret in L. phaeopa. With it the larvae can precisely fix the silken filaments to the wood surface. The sensilla chaetica on the ventral side of the spinneret may have a tactile function when the larva inserts the spinneret into cracks and openings on the wood surface for fixing the gallery-threads. Another important aspect is the flexibility of the posterior part of the spinneret, which is subdivided in such way that the dorsal part is pushed backwards. This plays an important role in attaching and fixing the threads to wood surfaces, where high pressure is useful for accurate fastening of the threads. The generally round shape of the silken filaments corresponds well with the shape of the spinneret orifice. Neophylax concinnus MacLachlan, 1871 and Pycnopsyche guttifer (Walker, 1852) secrete ribbon-like flat threads corresponding to the shape of the orifices of their spinnerets (Engster, 1976). This may be important for case- and retreat-making. Thus, as shown in Neophylax concinnus, flattened filaments are associated with case-making using round sand grains (Engster, 1976). The shapes of the spinneret orifices of larvae from different trichopteran families differ and may be adaptations to the larval life habits (Denis, 1984). Other net-spinning Trichoptera showed different patterns of net construction. Most Hydropsychidae build a systematically arranged series of robust nets with defined mesh sizes; the nets filter suspended particles from the water (Malicky, 1973). Polycentropodidae and Philopotamidae mainly construct loosely woven, mostly sack shaped nets without incorporating solid fragments. Whereas most Polycentropodidae are predators, feeding on small invertebrates that stray into their nets, Philopotamidae use the tip of their brushlike labrum to feed on detritus trapped in their nets (Malicky, 1973).

Our results indicate that the elongation of the spinneret in L. phaeopa and other psychomyiid larvae (Alecke, 1998) is closely associated with retreat-making. The retreat functions primarily as camouflage against predators, and in sandy streams as a shelter against drifting sand as well. Another very important aspect of this close insect-substrate association is the predetermination of larval life habitat by selective egg-deposition of females (Spänhoff et al., 2003). The larval performance might be interpreted as a subsequent co-development following the female preference for oviposition on wood in aquatic habitats.

ACKNOWLEDGEMENTS. Many thanks to Peter WibergLarsen for much advice and many comments, which greatly improved the manuscript, and Joe Lange for preparing the SEMphotographs. Additionally, we thank Pavel Štys and an anonymous reviewer for many important improvements and suggestions. The first author was supported by the Graduiertenfoerderung of the Federal State of Northrhine-Westphalia.

\section{REFERENCES}

ALdERSON R. 1969: Studies on the Larval Biology of Caddis Flies of the Family Psychomyiidae. PhD thesis, University of Wales, 114 pp.

ALECKE C. 1998: Ökologie und Habitatbindung von Tinodes unicolor und T. pallidulus (Trichoptera; Insecta). Münster, Schüling Verlag, 184 pp.

Anderson N.H., Steedman R.J. \& Dudley T. 1984: Patterns of exploitation by stream invertebrates of wood debris (xylophagy). Verh. Int. Verein. Theor. Angew. Limnol. 22: 1847-1852.

BECKER G. 1990: Comparison of the dietary composition of epilithic trichopteran species in a first-order stream. Arch. Hydrobiol. 120: 13-40.

Collier K.J. \& Halliday J.N. 2000: Macroinvertebrate-wood associations during decay of plantation pine in New Zealand pumice-bed streams: stable habitat or trophic subsidy. $J . N$. Am. Benthol. Soc. 19: 94-111.

DEnIs C. 1984: Fine structure of case-making larvae (Trichoptera). Proc. $4^{\text {th }}$ Int. Symp. Trichoptera: 105-114.

Dudley T. \& ANderson N.H. 1982: A survey of invertebrates associated with wood in aquatic habitats. Melanderia 39: $1-21$.

Dudley T.L. \& Anderson N.H. 1987: The biology and life cycles of Lipsothrix spp. (Diptera: Tipulidae) inhabiting wood in Western Oregon streams. Freshw. Biol. 17: 437-451.

Edington J.M. \& ALderson R. 1973: The taxonomy of British psychomyiid larvae (Trichoptera). Freshw. Biol. 3: 463-478.

ENGSTER M.S. 1976: Studies on silk secretion in the Trichoptera (F. Limnephilidae). I. Histology, histochemistry, and ultrastructure of the silk glands. J. Morph. 150: 183-212.

FAUCHEUX M.J. 1995: Sensilla on the larval antennae and mouthparts of the European sunflower moth, Homoeosoma nebulella Den. and Schiff. (Lepidoptera: Pyralidae). Int. J. Insect Morph. Embryol. 24: 391-403.

Gaino E. \& Rebora M. 1999: Larval antennal sensilla in waterliving insects. Microsc. Res. Tech. 47: 440-457.

Hickin N.E. 1950: Larvae of the British Trichoptera: 29 Lype reducta. Proc. R. Entomol. Soc. London (A) 25: 71-74.

Hickin N.E. 1954: Larvae of the British Trichoptera: 44 Lype phaeopa. Proc. R. Entomol. Soc. London (A) 29: 93-95.

HoFFMANN A. 2000: The association of the stream caddisfly Lasiocephala basalis (Kol.) (Trichoptera: Lepidostomatidae) with wood. Int. Rev. Hydrobiol. 85: 79-93.

KaUfman M.G. \& KING R.H. 1987: Colonization of wood substrates by the aquatic xylophage Xylotopus par (Diptera: Chironomidae) and a description of its life history. Can. J. Zool. 65: 2280-2286.

KeIL T. 1997: Functional morphology of insect mechanoreceptors. Microsc. Res. Tech. 39: 506-531.

Mackay R.J. \& Wiggins G.B. 1979: Ecological diversity in Trichoptera. Annu. Rev. Entomol. 24: 185-208.

MaLıCKY H. 1973: Trichoptera (Köcherfliegen). In: Helmcke J.G., Starck D. \& Wermuth H. (eds): Handbuch der Zoologie. IV. Band, 29. Berlin: Walter de Gruyter, 114 pp.

Matsuda R. 1965: Morphology and Evolution of the Insect Head. Memoirs of the American Entomological Institute No. 4, Ann Arbor, Michigan, $334 \mathrm{pp}$.

Pereira C.R.D., Anderson N.H. \& Dudley T. 1982: Gut content analysis of aquatic insects from wood substrates. Melanderia 39: 23-33.

Phillres E.C. 1997: Life cycle, growth, survival, and production of Macronychus glabratus (Coleoptera: Elmidae) in northwest Arkansas and southeast Texas streams. Invert. Biol. 116: 134-141. 
SATtLeR W. 1957: Beobachtungen an den Larven von Crunoecia irrorata Curt. (Trichoptera). Ber. Limnol. Flussstn Freudenthat 7: 18-32.

SATTLER W. 1967: Über die Lebensweise, insbesondere das Bauverhalten, neotropischer Eintagsfliegen-Larven (Ephemeroptera: Polymitarcidae). Beitr. Neotrop. Fauna 5: 89-110.

Schulte U., SpÄnhoff B. \& MeYer E.I.: Ingestion and utilization of wood by the larvae of two Trichoptera species, Lasiocephala basalis (Lepidostomatidae) and Lype phaeopa (Psychomyiidae). Arch. Hydrobiol. (in press)

SHIEldS V.D.C. 1994a: Ultrastructure of the uniporous sensilla on the galea of larval Mamestra configurata (Walker) (Lepidoptera: Noctuidae). Can. J. Zool. 72: 2016-2031.

SHELDS V.D.C. 1994b: Ultrastructure of the aporous sensilla on the galea of larval Mamestra configurata (Walker) (Lepidoptera: Noctuidae). Can. J. Zool. 72: 2032-2054.

SHIELDS V.D.C. 1996: Comparative external ultrastructure and diffusion pathways in styloconical sensilla on the maxillary galea of larval Mamestra configurata (Walker) (Lepidoptera: Noctuidae) and five other species. J. Morph 228: 89-105.

SLANSKY F. \& SCRIBER J.M. 1985: Food consumption and utilization. In: Kerkut G.A. \& Gilbert L.I. (eds): Comprehensive Insect Physiology, Biochemistry, and Pharmacology, Volume 4. Pergamon Press, Oxford, pp. 87-163.

SPÄNHOFF B., AleCKE C. \& MeYER E.I. 1999: The colonization of aquatic woody debris by Trichoptera, with special reference to the genus Lype (Psychomyiidae). Proc. $9^{\text {th }}$ Int. Symp. Trichoptera: $349-358$.

Spänhoff B., Alecke C., KascheK N. \& Meyer E.I. 2000a: Ökologie holzbesiedelnder aquatischer Makroinvertebraten am Beispiel der Trichopterengattung Lype (Psychomyiidae). Verh. Westdeutsch. Entomol. 1999, Düsseldorf 2000: 209-224.

Spänhoff B., Alecke C. \& Meyer E.I. 2000b: Colonization of submerged twigs and branches of different wood genera by aquatic macroinvertebrates. Int. Rev. Hydrobiol. 85: 49-66.

Spänhoff B., Alecke C., Kaschek N., Lange J. \& Meyer E.I. 2003: Morphological characteristics of sensilla on the female ovipositor of Lype phaeopa (Psychomyiidae; Trichoptera). $J$. Insect Sci. 3.12.: available online: insectscience.org/3.12

St Clair R.M. 1994: Diets of some larval Leptoceridae (Trichoptera) in south-eastern Australia. Aust. J. Mar. Freshw. Res. 45: 1023-1032.

SteEdMAn R.J. \& ANDERson N.H. 1985: Life history and ecological role of the xylophagous aquatic beetle, Lara avara LeConte (Dryopoidea: Elmidae). Freshw. Biol. 15: 535-546.

Steinbrecht R.A. 1997: Pore structure in insect olfactory sensilla: a review of data and concepts. Int. J. Insect Morph. Embryol. 26: 229-245.

ToBIAS W. 1996: Sommernächtliches, Schneetreiben' am Main. Natur Mus. 126: 37-54.

ToMASzEWSKi C. 1955: Studies on the influence of water microcurrents on Tinodes waeneri L. (Trichoptera). Ekol. Pol. Seria A 3: 85-99.

WiBERG-LARSEN P. 1995: Identification of Danish adult females of Lype (Trichoptera; Psychomyiidae), with notes on reproduction. Aquat. Insects 17: 65-70.

ZACHARUK R.Y. \& SHELDS V.D. 1991: Sensilla of immature insects. Annu. Rev. Entomol. 36: 331-354.

Received October 29, 2002; revised April 8, 2003; accepted June 17, 2003 